\title{
Tetany despite normocalcaemia and normomagnesaemia following parathyroidectomy
}

\author{
V.A. Fonseca, R.D. Bloom, R. Dick' and P. Dandona \\ Metabolic Unit, Department of Chemical Pathology and Human Metabolism, and ' Department of Radiology, \\ Royal Free Hospital and School of Medicine, Pond Street, London NW3 2QG, UK.
}

\begin{abstract}
Summary: Two patients with long-standing hyperparathyroidism due to a parathyroid adenoma are described. Both had severe osteitis fibrosa cystica and a proximal myopathy. Both were treated with alfacalcidol $(2 \mu \mathrm{g} / \mathrm{day})$ prior to and following parathyroidectomy, and infused with calcium gluconate following the operation. Plasma total and ionized calcium and magnesium concentrations were maintained within the normal range. However, both developed tetany in the postoperative period in spite of normal ionized calcium and magnesium concentrations. Tetany continued for 4 weeks in one patient and for longer in the other. Prolonged hypercalcaemia may result in a state of neuromuscular excitability following parathyroidectomy even at high normal concentrations of ionized calcium.
\end{abstract}

\section{Introduction}

Hypocalcaemia is commonly associated with tetany following parathyroidectomy for primary hyperparathyroidism. It can be prevented by maintaining normal calcium concentrations through the administration of vitamin $D$ analogues and calcium infusions. ${ }^{1}$ We have recently observed two patients in whom tetany occurred in spite of successful maintenance of normal plasma calcium and magnesium concentrations following the removal of a parathyroid adenoma. This phenomenon, to our knowledge, is hitherto unreported.

\section{Case reports}

\section{Case 1}

A 25 year old male Nigerian presented with bilateral hip pain and difficulty in walking. On examination, there was painful limitation of hip movement bilaterally, and upper and lower girdle weakness.

Investigations: fasting plasma calcium $3.21 \mathrm{mmol} / 1$ (normal 2.2-2.6 mmol/1); phosphate $0.61 \mathrm{mmol} / 1$ (normal $0.9-1.3 \mathrm{mmol} / \mathrm{l}$ ); alkaline phosphatase $1400 \mathrm{IU} / 1$ (normal 70-130 IU/1); urea $4.8 \mathrm{mmol} / \mathrm{l}$; sodium $136 \mathrm{mmol} / \mathrm{l}$; potassium $4.1 \mathrm{mmol} / \mathrm{l}$; bicarbonate $22 \mathrm{mmol} / \mathrm{l}$; parathyroid hormone (PTH) (midmolecule) $>1000 \mathrm{pmol} / 1$ (normal $25-85 \mathrm{pmol} / \mathrm{l}$ ). $\mathrm{X}$-rays of the pelvis showed gross osteitis fibrosa

Correspondence: P. Dandona, D. Phil., M.R.C.P.

Accepted: 26 March 1986 cystica. The patient underwent surgery and a $3 \times 1 \mathrm{~cm}$ left upper parathyroid adenoma was excised.

On the day before the operation, the patient was given $1 \mu \mathrm{g}$ of $1 \alpha$-hydroxycholcalciferol (alfacalcidol) orally; this was continued postoperatively at a dose of $2 \mu \mathrm{g} / \mathrm{day}$, along with an intravenous infusion of calcium gluconate (total daily dose: $\mathbf{4} \mathrm{g}$ of calcium). The plasma calcium dropped to 2.86 and $2.72 \mathrm{mmol} / 1$ 4 and 8 hours postoperatively respectively. Twitching of the leg muscles and paraesthesiae in the hands and around the mouth started the following day. Chvostek's sign was positive. His plasma total calcium was $2.52 \mathrm{mmol} / \mathrm{l}$ and ionized calcium $1.24 \mathrm{mmol} / 1$ (normal range: $1.05-1.30 \mathrm{mmol} / \mathrm{l})$. The calcium infusion and oral alfacalcidol were continued. Plasma magnesium concentration was $0.61 \mathrm{mmol} / 1$ (normal range: $0.7-$ $1.0 \mathrm{mmol} / \mathrm{l})$. Magnesium sulphate $(50 \mathrm{mmol} / \mathrm{day})$ was infused; plasma magnesium rose to $0.95 \mathrm{mmol} / \mathrm{l}$. Thereafter, magnesium concentrations were maintained well within the normal range. However, the patient continued to have tingling and numbness of digits and tetany with a positive Chvostek's sign over the next 4 weeks (results of plasma calcium are summarized in Table I). Arterial blood gases were performed twice and revealed a normal $\mathrm{pH}$ (7.42).

\section{Case 2}

A 48 year old Greek male presented with progressive painful proximal myopathy of 5 years duration. The proximal muscles were markedly tender.

Investigations: fasting plasma calcium $3.10 \mathrm{mmol} / \mathrm{l}$; 
Table I Plasma calcium (Ca), magnesium $(\mathrm{Mg})$ and potassium $(\mathrm{K})$ concentrations (mmol/l) as related to neuromuscular irritability.

\begin{tabular}{|c|c|c|c|c|c|c|c|c|c|c|}
\hline Day & $\mathrm{Ca}$ & $M g$ & $\begin{array}{c}\text { Patient } 1 \\
K\end{array}$ & $S C P S$ & $C S$ & $\mathrm{Ca}$ & $M g$ & $\begin{array}{c}\text { Patient } 2 \\
K\end{array}$ & $S C P S$ & $C S$ \\
\hline $\begin{array}{l}\text { Preoperative } \\
\text { Postoperative }\end{array}$ & 3.21 & & 4.1 & & - & 3.10 & & 4.2 & - & - \\
\hline Day 1 & 2.52 & 0.61 & 3.9 & + & + & 2.32 & 0.80 & 4.0 & + & + \\
\hline 2 & 2.55 & 0.95 & 4.1 & + & + & 2.36 & & 4.1 & + & + \\
\hline 8 & 2.46 & 0.85 & & + & + & 2.36 & & & + & + \\
\hline 15 & 2.41 & 0.82 & & - & + & 2.35 & 0.85 & & - & + \\
\hline 28 & 2.38 & & - & - & - & & & & & \\
\hline 90 & 2.45 & 0.86 & & - & - & & & & & \\
\hline
\end{tabular}

SCPS = spontaneous carpopedal spasms; $\mathrm{CS}=$ Chvostek's sign.

phosphate $0.36 \mathrm{mmol} / \mathrm{l}$; alkaline phosphatase $2170 \mathrm{IU} / \mathrm{l}$; albumin $40 \mathrm{~g} / \mathrm{l}$; potassium $4.2 \mathrm{mmol} / \mathrm{l}$; bicarbonate $19 \mathrm{mmol} / \mathrm{l}$; chloride $109 \mathrm{mmol} / \mathrm{l}$; PTH > $1000 \mathrm{pmol} / \mathrm{l}$. X-rays and a bone scan showed evidence of severe hyperparathyroidism, including osteitis fibrosa cystica in the fibula, which was confirmed by biopsy.

A large left inferior parathyroid adenoma was removed at surgery. The patient was treated with alfacalcidol before and after the operation and was intravenously infused with calcium gluconate, as in Case 1. Four hours after the operation, his plasma calcium had fallen to $2.83 \mathrm{mmol} / \mathrm{l}$; at $24 \mathrm{~h}$, it was $2.32 \mathrm{mmol} / \mathrm{l}$. Paraesthesiae and carpal spasms commenced and Chvostek's sign became positive. Plasma magnesium was $0.8 \mathrm{mmol} / \mathrm{l}$, ionized calcium $1.16 \mathrm{mmol} / \mathrm{l}$ and arterial blood $\mathrm{pH} 7.42$. These signs and sypmtoms persisted for at least 3 weeks (he returned to Greece at this stage), in spite of maintaining normal calcium and magnesium concentrations.

Radiological examination of the bones at 6 months showed virtual resolution of the osteitis fibrosa cystica. The proximal weakness and muscle pain also resolved.

\section{Discussion}

The rapid fall in plasma calcium concentration in these

\section{References}

1. Parsons, V., Jones, R., Weston, M. et al. The use of $1 \alpha-$ hydroxyvitamin $\mathrm{D}_{3}$ in the management of patients undergoing parathyroidectomy. Clin Endocrinol (Oxford) 1977, 7 (suppl): 223-224.

2. Reddy, V. \& Sivakumar, B. Magnesium dependent vitamin D resistant rickets. Lancet 1974, i: 963-965.

3. Rude, R.K., Oldham, S.B. \& Singer, F.R. Functional two cases with severe hypercalcaemia and hyperparathyroidism resulted in neuromuscular irritability $\infty$ in spite of the maintenance of total and ionic calcium or concentrations within the normal range, suggesting 을 that these tissues had adapted to the high calcium concentrations over a long period of time. The extent $O$ of bone disease and the long history in our patients are consistent with the hypothesis that they had had $\underset{\mathbb{D}}{\mathscr{C}}$ primary hyperparathyroidism and hypercalcaemia for several years before surgery. Both patients had large parathyroid adenomata, severe hyperparathyroidis and florid osteitis fibrosis cystica.

This phenomenon has probably been observed before, but there has been no objective report of the phenomenon with concomitant measurements of plasma ionized calcium and magnesium concentrations. Both measurements are important since hypomagnesaemia can reduce end organ responses to both vitamin $\mathrm{D}^{2}$ and $\mathrm{PTH}^{3,4}$ as well as suppressing PTH secretion from the remaining parathyroid glands.

In conclusion, tetany may occur following parathyroidectomy despite normocalcaemia and normomagnesaemia if the patient has had prolonged and severe hypercalcaemia prior to the operation. The neuromuscular irritability may persist for several weeks until the tissues 'adapt' to a 'normal' plasma $ᄋ$ calcium concentration.

hypoparathyroidism and parathyroid hormone end organ resistance in human magnesium deficiency. Clin Endocrinol (Oxford) 1976, 5: 209-214.

4. Fonseca, V.A. \& Havard, C.W.H. Electrolyte disturbances and cardiac failure with hypomagnesaemia in anorexia nervosa. Br Med J 1985, 291: 680-682. 